CZASOPISMO INŻYNIERII LĄDOWEJ, ŚRODOWISKA I ARCHITEKTURY JOURNAL OF CIVIL ENGINEERING, ENVIRONMENT AND ARCHITECTURE

JCEEA, t. XXXIV, z. 64 (3/II/17), lipiec-wrzesień 2017, s. 79-90, DOI:10.7862/rb.2017.155

\author{
Marek GOSZTYLA ${ }^{1}$ \\ Agata MIKRUT $^{2}$
}

\title{
URBANISTYKA MIASTA RZESZOWA W ASPEKTACH HISTORYCZNYCH
}

\begin{abstract}
W artykule został opisany rozwój struktury przestrzennej miasta Rzeszowa. Kształtowanie się tego ośrodka było procesem trwającym kilka wieków. Proces formowania tkanki miasta został podzielony na etapy, których wyznacznikiem są przełomowe wydarzenia historyczne. W artykule scharakteryzowano urbanistykę Rzeszowa, zaczynając od opisu badań archeologicznych dotyczących pierwszych osad na tym terenie, a kończąc na czasach współczesnych. Załączone mapy i plany obrazują zmiany przestrzenne struktury miasta. Nadrzędnym celem artykułu było przedstawienie usystematyzowanego procesu urbanistycznego stolicy podkarpacia. W tekście przywołano istotne aspekty $\mathrm{z}$ bogatej i różnorodnej historii miasta, przedstawiając ich znaczenie w procesie formowania się struktury dzisiejszego Rzeszowa. Artykuł może przyczynić się do wyznaczenia kierunków dalszego rozwoju miasta.
\end{abstract}

Słowa kluczowe: urbanistyka, miasto, rozwój przestrzenny, architektura Rzeszowa

Struktura przestrzenna Rzeszowa formowała się w długim procesie złożoności, który trwał przez kilka wieków. Położenie Rzeszowa w dużym stopniu wpłynęło na znaczenie tego ośrodka. Zmiany tkanki urbanistycznej zostały przedstawione w artykule poprzez wyszczególnienie faz rozwoju miasta. Rozwój układu urbanistycznego dzisiejszej stolicy województwa podkarpackiego przedstawiono od początków osadnictwa po czasy współczesne.

Proces kształtowania się struktury przestrzennej miasta Rzeszowa można podzielić na kilka etapów. Pierwszy etap to okres formowania się pierwszych osad, zlokalizowanych wzdłuż rzeki Wisłok. Drugi etap to założenie miasta lokacyjnego. Następny wiąże się z rozwinięciem przedmieść poza obrębem średniowiecznego miasta. Czwarty etap dotyczy okresu powstania zamku i łączenia

1 Autor do korespondencji/corresponding author: Marek Gosztyła, Politechnika Rzeszowska, Katedra Konserwacji Zabytków, al. Powstańców Warszawy 12, 35-959 Rzeszów; tel.: 17865 1939; e-mail: gosztyla@prz.edu.pl

${ }^{2}$ Agata Mikrut, Politechnika Rzeszowska, Katedra Konserwacji Zabytków, al. Powstańców Warszawy 12, 35-959 Rzeszów; tel.: 17743 2106; e-mail: a.mikrut@prz.edu.pl 
siedziby właściciela z miastem. W tym czasie Rzeszów rozwijał się w kierunku południowym. Kolejna przebudowa zamku, przez rodzinę Lubomirskich, stanowi następną fazę rozwoju struktury przestrzennej miasta. Okres rozbiorów, będący szóstym etapem, doprowadził do zniekształcenia układu urbanistycznego. Dopiero okres autonomii galicyjskiej zapoczątkował kolejny ważny etap rozwoju miasta. Było to związane między innymi z budową nowych obiektów i rozwojem infrastruktury drogowej. Okres międzywojenny stanowi ósmą fazę w historii rozwoju Rzeszowa, związaną szczególnie z budową Centralnego Okręgu Przemysłowego. Tuż po drugiej wojnie światowej nastąpiła odbudowa miasta, powstały osiedla na południe od centrum oraz zostały poszerzone granice miasta - dziewiąty etap. Budowa obiektów mieszkalnych na północ i zachód od centrum, po 1960 roku, a także wybudowanie obwodnicy południowej wyznaczyły kolejną fazę rozwoju Rzeszowa. ${ }^{3}$ Poszerzenie granic miasta, poprzez włączanie przylegających miejscowości, na początku XXI wieku ponownie zmieniło strukturę miasta.

Wykopaliska archeologiczne na terenie obecnego Rzeszowa wskazują na pojawienie się pierwszych stałych osad w okresie neolitu. Najlepiej przebadane stanowisko archeologiczne, znajdujące się na terenie dzisiejszego osiedla Piastów, jest miejscem najstarszej osady neolitycznej. Kolejne zostały odkryte na Staromieściu, w rejonie Lisiej Góry, a także na terenie Pobitna i Słociny. Z epoki brązu i wczesnej epoki żelaza pochodzą ślady osadnictwa na obszarach obecnego osiedla Baranówka. ${ }^{4} \mathrm{~W}$ tym okresie doszło do dynamicznego rozwoju osadniczo-ludnościowego na terenach Polski południowo-wschodniej. Nastąpiły zmiany dotyczące koncentracji osad oraz kształtowania się sieci mikroregionalnych struktur osadniczych w rejonach wielkich dolin rzecznych. W pierwszych wiekach nowej ery na rozwój osadnictwa miała wpływ ludność tzw. kultury przeworskiej. Na przełomie V i VI wieku, po krótkim okresie pustki, ze wschodu napłynęła na te tereny fala pierwszych osadników słowiańskich. ${ }^{5} \mathrm{Z}$ okresu przedlokacyjnego znane są średniowieczne osady tzw. otwarte, lokowane w obrębie granic dzisiejszego miasta Rzeszowa. Zabudowę mieszkalną osad stanowiły ziemianki i półziemianki. W rejonie obecnego osiedla Tysiąclecia znajdowała się wówczas największa osada wczesnośredniowieczna. Inne zostały odkryte w rejonie Staromieścia, a także Pobitna i Załęża. ${ }^{6}$ Według niektórych badaczy, na terenach obecnego Rzeszowa, równolegle $\mathrm{z}$ istnieniem osad targowych istniał gród obronny. Jednak jego lokalizacja pozostaje niejasna i nie została potwierdzona archeologicznymi wykopaliskami. Wczesnośredniowieczna osada ze względu na korzystne warunki geograficzne i gospodarcze została ulokowana w kotlinie rzeki Wisłok. O istnieniu osady świadczą przeprowadzone

\footnotetext{
${ }^{3}$ W. Hennig, Rozwój przestrzenny miasta, [w:] Encyklopedia Rzeszowa, Rzeszów 2004, s. 536.

${ }^{4}$ A. Kunysz, W pradziejach $i$ wczesnym średniowieczu, [w:] Dzieje Rzeszowa Tom I, Rzeszów 1994, s. 88-91.

${ }^{5}$ S. Czopek, Historia, [w:] Encyklopedia Rzeszowa, Rzeszów 2004, s. 158-159.

${ }^{6}$ G. Zamoyski, Historia, [w:] Encyklopedia Rzeszowa, Rzeszów 2004, s. 159.
} 
badania archeologiczne oraz analizy późniejszego stanu osadnictwa tych terenów. ${ }^{7}$

Plany Rzeszowa na podstawie których zostało uformowane średniowieczne miasto nie są znane. ${ }^{8}$ Około roku 1340 lub 1341, król Kazimierz Wielki przyłączył ziemię sanocką i przemyską do Polski. Najstarszy dokument źródłowy, dotyczący przejścia włości rzeszowskiej w ręce prywatne, pochodzi z 1354 roku. ${ }^{9}$ Król Kazimierz Wielki nadał, funkcjonujące już wówczas na prawie magdeburskim, miasto Rzeszów Janowi Pakosławicowi, w przywileju zezwolił na dalsze pobieranie cła „starodawnego", co potwierdza dotychczasową targową funkcję miasta. ${ }^{10}$ Nowe miasto lokacyjne częściowo objęło istniejącą osadę, zlokalizowaną w okolicach późniejszej fary. Miasto lokacyjne zajmowało również teren pagórka, stanowiący obecnie Rynek. ${ }^{11}$ Po pożarze w 1427 r., właściciele wystąpili o ponowny przywilej lokacyjny. Część obiektów zniszczonych w pożarze zaczęto odbudowywać jako murowane, jak np. kościół parafialny. ${ }^{12}$ Mikołaj Rzeszowski dnia 25 czerwca 1571 r. wydał dokument, w którym potwierdził dotychczasowe oraz nadał nowe przywileje, regulujące kwestie związane $\mathrm{z}$ organizacją miasta. ${ }^{13}$

Przełom XVI i XVII wieku to okres znaczącego rozwoju urbanistycznego Rzeszowa. Rządy Mikołaja Spytka Ligęzy, związane z gospodarczym ożywieniem miasta skutkowały dynamicznym wzrostem liczby mieszkańców. ${ }^{14} \mathrm{~W}$ tym czasie Rzeszów zamieszkiwało ponad trzy tysiące osób. Miało to swoje odbicie w intensywnym rozwoju przestrzennym miasta. Mikołaj Spytek Ligęza był fundatorem wielu budowlanych inwestycji, które znacząco wpłynęły na krajobraz ówczesnego Rzeszowa. Podjęte przez niego działania wynikały zarówno ze względów praktycznych jak i estetycznych. W mieście został wybudowany m.in. nowy ratusz, waga i kramy, szpital-dom dla ubogich. Z inicjatywy Ligęzy wybudowano murowany kościół wraz z klasztorem OO. Bernardynów. ${ }^{15} \mathrm{Z}$ urbanistycznego punktu widzenia największą zmianą w tym okresie było powstanie

7 A. Kunysz, W pradziejach $i$ wczesnym średniowieczu, [w:] Dzieje Rzeszowa tom I, Rzeszów 1994, s. 88- 91.

8 W. Hennig, Plany i koncepcje zagospodarowania przestrzennego miasta, [w:] Encyklopedia Rzeszowa, Rzeszów 2004, s. 444.

9 J. Kurtyka, Osadnictwo Średniowieczne. Początki osady i miasta [w:] Dzieje Rzeszowa tom I, Rzeszów 1994, s. 97-98.

${ }^{10}$ M. Borowiejska-Birkenmajerowa, Rozwój przestrzenny..., [w:] Dzieje Rzeszowa tom I, Rzeszów 1994, s.172.

${ }^{11}$ Z. Wójcik, Historia, [w:] Encyklopedia Rzeszowa, Rzeszów 2004, s. 160.

12 J. Malczewski, R. Kwolek, Historia i Rozwój przestrzenny Rzeszowa od powstania do wspótczesności [w:] Renowacje i Zabytki 3/2015, s.45.

13 W. Zawitkowska, G. Zamoyski, Przywileje miasta Rzeszowa XIV-XIX wieku, Rzeszów 2014, s.62.

14 J. Pęckowski, Dzieje miasta Rzeszowa do końca XVIII wieku : z 21. rycinami w tekście, Rzeszów 1913, s.24-25.

${ }^{15}$ Gosztyła M., Jagieła B., Konserwacja zabytków architektury- teoria i praktyka działań konserwatorskich na przyktadzie reprezentatywnych kościołów Rzeszowa, Rzeszów 2015, s.45. 
Nowego Miasta. Założenie nowej osady rzemieślniczo-handlowej spowodowało decentralizację obszaru Rzeszowa. Nowe Miasto powstało z konieczności poszerzenia terytorium istniejącego miasta i posiadało całkowicie odrębny układ urbanistyczny. Pomiędzy obszarem średniowiecznego miasta a Nowym Miastem, znajdowała się dzielnica żydowska z murowanym budynkiem synagogi. $\mathrm{Z}$ czasem zabudowa domów żydowskich zaczęła wkraczać na teren Nowego Miasta. Ligęza rozpoczął również wznoszenie zamku z systemem fortyfikacji, który stanowił jeden $\mathrm{z}$ elementów rozwiniętego układu przestrzennego Rzeszowa sprzężonego ze średniowiecznym miastem, Nowym Miastem oraz obronnym zespołem bernardyńskim. ${ }^{16}$

Około połowy XVII wieku Rzeszów stał się miastem rezydencjonalnym rzeszowskiej linii rodu Lubomirskich. Lubomirski założył w Rzeszowie kolegium Pijarów, które w krótkim czasie stało się słynną szkołą i przyczyniło się do kulturalnego rozkwitu miasta. Kolejni spadkobiercy zajęli się rozbudową miasta. Hieronim Augustyn Lubomirski zlecił przebudowę zamku i fortyfikacji Tylmanowi z Gameren. Architekt zaprojektował przebudowę zamku i jego fortyfikacji w typie pallazzo in fortezza około roku 1687. ${ }^{17}$ Tylman van Gameren jest pierwszym znanym z nazwiska twórcą planów urbanistycznych dla miasta Rzeszowa. Jego plany- przebudowa zamku, rozbudowa założenia klasztoru Bernardynówrealizował także inny architekt, Pietro Martire Belotti. Młodszy Belotti (Jan Chrzciciel) prowadził końcowe prace przebudowy zamku. Zaprojektowany przez niego kościół reformacki oraz dzwonnica kościoła farnego, istniejące do dnia dzisiejszego, stanowią charakterystyczne akcenty w kompozycji wnętrza miasta. $^{18}$

Pod koniec lat dwudziestych XVIII wieku stanowisko nadwornego architekta Lubomirskich objął Karol Henryk Wiedemann. Zajął się on przebudową rzeszowskiego zamku po pożarze z 1735 roku, realizacją założeń przestrzennych dzielnicy zamkowej, nadbudową i przebudową Pałacu Letniego, a także modernizacją i rozbudową fortyfikacji zamkowych. ${ }^{19} \mathrm{Na}$ akwareli Wiedemanna przedstawiającej widok Rzeszowa z 1762 roku (rys. 1), zauważalne jest założenie ogrodowe przy Pałacu Letnim. Pałacowy ogród był połączony z ogrodem zamkowym, który również został w tym czasie przebudowany. ${ }^{20}$ Obszar tych ogrodów i innych przestrzennych założeń dzielnicy zamkowej oraz ogród pijarski łącznie zajmowały teren większy od Starego Miasta i Grodziska. Kompozycyjnie i funkcjonalnie rzeszowskie, późnobarokowe założenia ogrodowe odpowia-

${ }^{16}$ M. Borowiejska-Birkenmajerowa, Rozwój przestrzenny... op.cit., s. 260 -265.

${ }^{17}$ J. Nieć, Rzeszowskie za Sasów : szkic historyczny, Rzeszów 1938, s. 15-16.

${ }^{18}$ M. Borowiejska-Birkenmajerowa, Rozwój przestrzenny... op.cit., s. 307.

${ }^{19}$ J. Malczewski, Zamek w Rzeszowie, jego otoczenie i wtaściciele, Rzeszów 1994, s. 20-27.

${ }^{20}$ Rucka-Marmaj D., Letni patac Lubomirskich w Rzeszowie, [w:] Renowacje i Zabytki 3/2015, s. $74-81$. 
dały postulatom swojej epoki. ${ }^{21}$ Podczas konfederacji barskiej (1768-1772) miasto i zamek zostały znacznie zniszczone (rys. 1.).

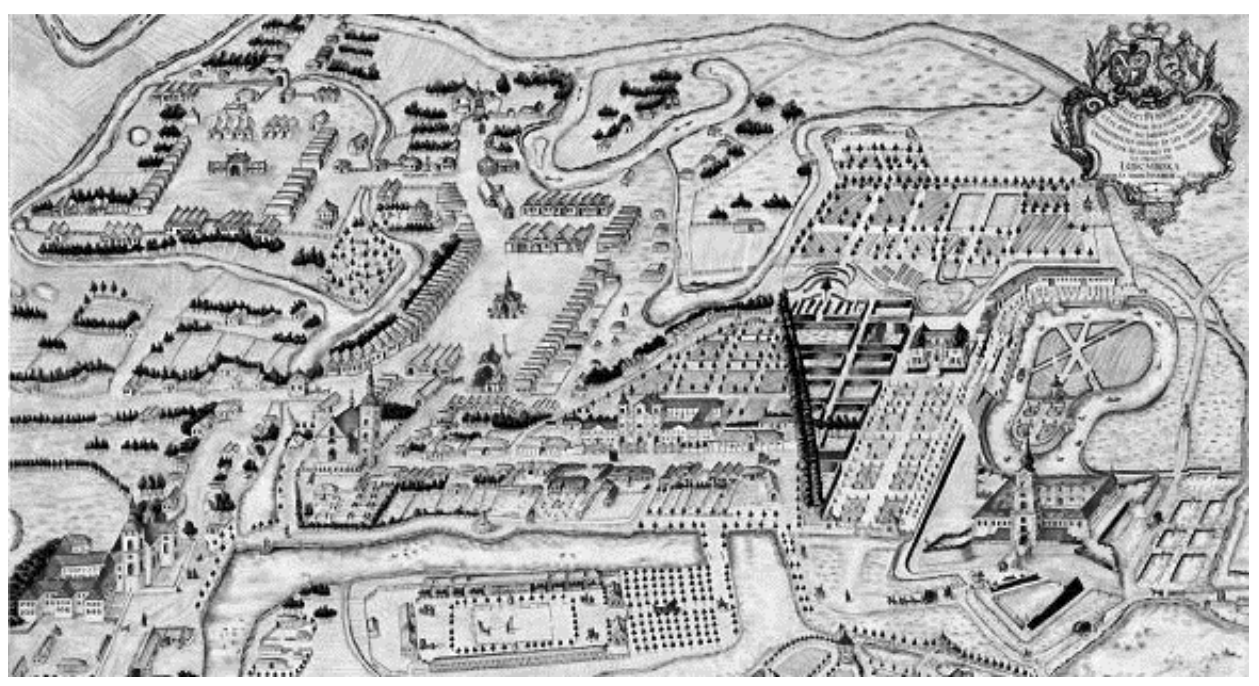

Rys. 1. Widok Rzeszowa z 1762 roku, plan K. H. Wiedemanna. Zbiory Muzeum Okręgowe w Rzeszowie

Fig. 1. The view of Rzeszów from 1762, K. H. Wiedemann's plan. In the collection of Regional Museum in Rzeszów

Analizując austriacką mapę z okresu 1763-1787 (rys. 2a) wyraźnie widać trzy rozległe jeziora od strony zachodniej oraz rzekę wraz z jej zakolami, a pomiędzy nimi najbardziej zwartą część zabudowy. Trapezowaty kształt rynku od strony północno-wschodniej i północno-zachodniej łączy się z głównymi drogami. Taki przebieg komunikacji ukształtował pierzeję północną rynku, wydłużając ją w obu kierunkach. Charakterystycznym elementem mapy jest kościół OO. Bernardynów, narysowany w widoku, zlokalizowany przy głównej drodze prowadzącej od strony północno-zachodniej w kierunku rynku. Przebieg tej drogi zmienił się jedynie we fragmencie od kościoła do rynku. Świątynia wzniesiona w I połowie XVII wieku, na miejscu poprzedniego drewnianego kościoła, stanowi jeden z najznamienitszych zabytków miasta. ${ }^{22}$

Na kolejnej austriackiej mapie (1806-1869) (rys. 2b) ten odcinek drogi skierowany jest na plac przed kościołem farnym a nie za nim. Od strony południowej biegną dwie drogi, które łączą się w jedną prowadzącą do centrum. Wzdłuż

${ }^{21}$ M. Borowiejska-Birkenmajerowa, Rozwój przestrzenny... op.cit., s.308-311.

22 M. Gosztyła, B. Jagieła, Konserwacja zabytków architektury - teoria i praktyka dziatań konserwatorskich na przykładzie reprezentatywnych kościołów Rzeszowa, Rzeszów 2015, s.43. 
niej przebiega zwarta zabudowa, dzisiejszej ulicy 3-go maja. Jej oś kompozycyjna z północnej strony kończy się kościołem farny, natomiast z południowej zamyka ją widok na zamek. Po przeciwnej stronie zamku, na południowy - zachód wyraźnie zaznaczony został kościół reformacki wraz z ogrodami otoczony murami. Oprócz zwartej zabudowy centrum, intensywnie rozwija się zabudowa na północny wschód od rynku, gdzie przebiega droga w kierunku Lwowa z mostem na rzece Wisłok. Na drugiej mapie austriackiej (rys. 2b) widać w tej części urbanistyczny układ Nowego Miasta z prostokątnym placem większym niż rynek starego miasta. Na tej samej mapie, w północnej części miasta, zaznaczony został przebieg linii kolejowej Kraków - Lwów i budynek kolei, poprowadzonej przez Rzeszów w 1858 roku.

a)

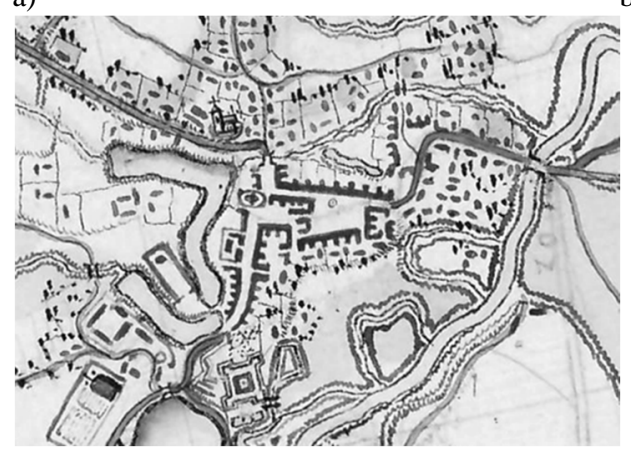

b)

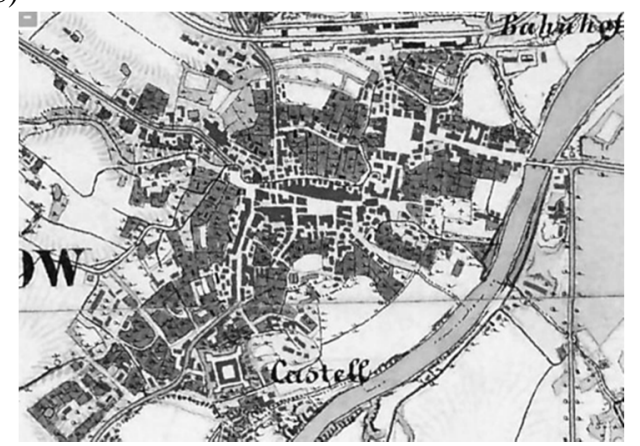

Rys. 2. Mapy austriackie - Rzeszów: a) (1763-1787), b) (1806-1869); http://mapire.eu Fig. 2 . Maps of the Habsburg Empire - Rzeszow: a) (1763-1787), b) (1806-1869); http://mapire.eu

W okresie rozbiorów układ urbanistyczny miasta uległ znacznym przekształceniom. Po pierwszym rozbiorze Polski Rzeszów stał się stolicą najpierw pilzneńskiego, a następnie rzeszowskiego cyrkułu. Administracyjny charakter miasta podniósł jego rangę i stwarzał perspektywy dalszego rozwoju ośrodka. Pod koniec XVIII wieku austriackie władze na obszarze całej Galicji budowały drogi handlowe i strategiczne. Pierwszą inwestycją była tzw. droga cesarska (z Bielska, przez Kraków, Tarnów, Przemyśl do Lwowa), która objęła również Rzeszów, przyczyniając się w ten sposób do jego rozwoju. ${ }^{23}$ Przebieg tej drogi zdeterminował również urbanistyczny rozwój Rzeszowa na osi wschód-zachód. W drugiej połowie XVIII wieku powierzchnia Rzeszowa wraz z użytkami rolnymi wynosiła ok. $2,9 \mathrm{~km}^{2}$ (rys. 3.) ${ }^{24}$.

Nowe funkcje polityczne i gospodarcze miasta osłabiły pozycje właścicieli i przyczyniły się do wyprzedania rzeszowskich posiadłości rodziny Lubomir-

23 J. Malczewski, Przestrzén miejska, jej zagospodarowanie i zabudowa, [w:] Dzieje Rzeszowa Tom II, Rzeszów 1998, s.23.

${ }^{24}$ Tamże, s.18. 
skich. Rodzina przeniosła swoją siedzibę do Chrzanowic, a ostatecznie we wrześniu 1844 roku miasto odkupiło ostatnie prawa dominialne od Jerzego Lubomirskiego. ${ }^{25}$

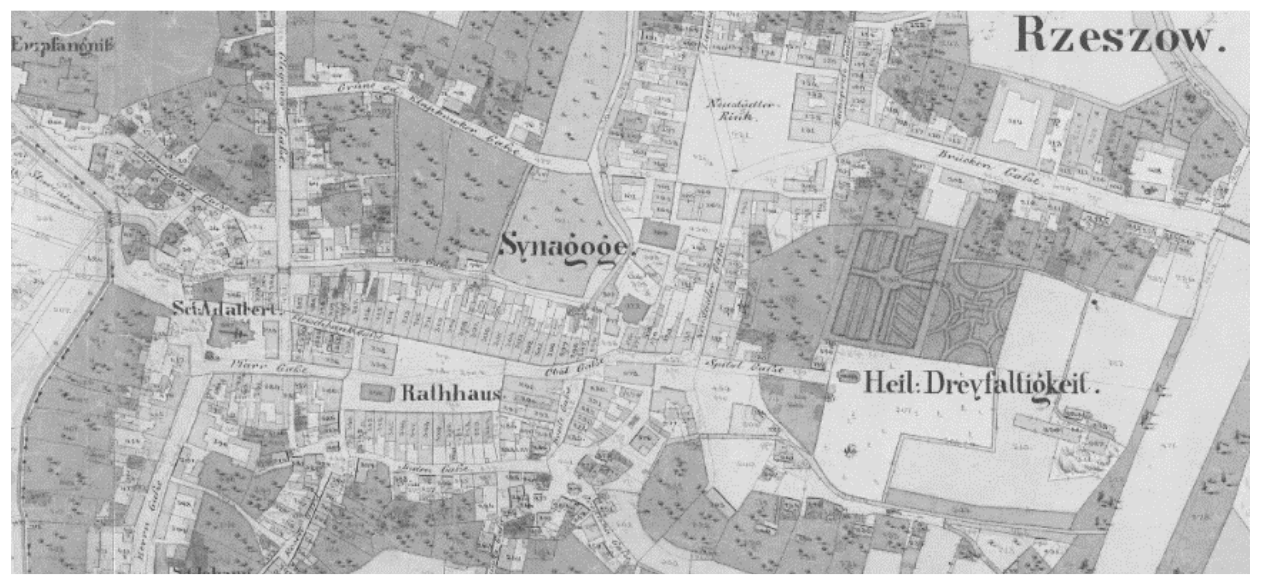

Rys. 3. Rzeszów mapa z 1849 r. Archiwum Państwowe w Przemyślu, na podstawie: przemysl. ap.gov.pl/skany/

Fig. 3. Map of Rzeszow in 1849. National Archive in Przemyśl, based on przemysl.ap. gov.pl/skany/

Kolejne przekształcenia struktury przestrzennej Rzeszowa nastąpiły w okresie autonomii galicyjskiej. Miasto było w tym czasie siedzibą władz administracyjnych i sądowniczych. Funkcje miasta miały znaczący wpływ na przekształcenie centrum miasta, budowę nowych, reprezentacyjnych obiektów oraz przebudowę istniejących. ${ }^{26}$ Istotna była budowa dróg państwowych oraz linii kolejowych. Granice administracyjne miasta zostały poszerzone o obszar Ruskiej Wsi i fragment Drabinianki, który włączono po regulacji koryta Wisłoka. Zajęto się również budową zespołów koszarowych i urządzaniem cmentarzy $^{27}$ (rys. 4.).

Po I wojnie światowej, która przerwała rozwój miasta, nastąpiła odbudowa pozycji Rzeszowa w niepodległej Polsce. Budowa Centralnego Okręgu Przemysłowego skutkowała, oprócz lokalizacji zakładów przemysłowych, budową osiedli pracowniczych oraz poprawą infrastruktury miejskiej. Skala śródmieścia uległa zmianie. ${ }^{28}$ Przemysł był głównym czynnikiem miastotwórczym. Inwesty-

${ }^{25}$ S. Czopek, Historia, [w:] Encyklopedia Rzeszowa, Rzeszów 2004, s.162.

${ }^{26}$ J. Malczewski, Rozwój przestrzenny. Rozbudowa miasta., [w:] Dzieje Rzeszowa Tom II, Rzeszów 1998, s.245.

${ }^{27}$ W. Hennig, Plany i koncepcje zagospodarowania przestrzennego miasta, [w:] Encyklopedia Rzeszowa, Rzeszów 2004, s. 537.

28 W. Hennig, Plany i koncepcje zagospodarowania przestrzennego miasta, [w:] Encyklopedia Rzeszowa, Rzeszów 2004, s.538. 
cje związane z COP stały się impulsem do rozpoczęcia planowania urbanistycznego. W marcu 1939 r. powstał „Ogólny plan zabudowania miasta Rzeszowa” opracowany przez architektów: K. Dziewońskiego i W. Śmigielskiego. Plan zabudowania przewidywał osiem sąsiedzkich dzielnic o charakterze mieszkaniowym, robotniczym i willowym. Zakładano wzrost liczby mieszkańców z 41 tys. do 100 tys. w ciągu 30 lat. ${ }^{29}$ Po raz kolejny wojna przerwała intensywny rozwój przestrzenny miasta (rys. 4.). W jej wyniku zniszczony został rejon Starego Miasta (rys. 5.). Kolejny plan ogólnego zagospodarowania opracował Z. Wzorek w latach 1947-1949. Do opracowania szczegółowego planu zagospodarowania Śródmieścia doszło w latach 1950-1953. Architekt Wzorek w swojej koncepcji uwzględnił założenia poprzedniego planu K. Dziewońskiego i W. Śmigielskiego odnoszące się przede wszystkim do skali i głównych kierunków rozbudowy Rzeszowa. Autor nowego planu zwrócił jednak większą uwagę na rolę centrum miasta i lokalizację nowych budynków administracyjnych oraz na znaczenie terenów zielonych. Założył odbudowę niektórych zabytkowych założeń urbanistycznych, zniszczonych podczas wojny. Dzielnice zlokalizowane na południe od centrum, połączyły się z rejonem śródmieścia. Miasto stało się ośrodkiem wojewódzkim. Nowa funkcja administracyjna wymagała powstania kolejnych obiektów. Struktura przestrzenna uległa funkcjonalizacji poprzez budowę dzielnic przemysłowo-składowych i rozwój sieci komunikacyjnej. ${ }^{30}$ W roku 1951 doszło do znacznego poszerzenia granic Rzeszowa poprzez przyłączenie pobliskich wsi takich jak Drabinianka, Pobitno, Staromieście i Staroniwa oraz część Słociny, Zalesia i Zwieńczycy. Powierzchnia miasta zmieniła się z 768 do 4032 ha. Lata 1949-1953 to okres intensywnego rozwoju budownictwa mieszkalnego w Rzeszowie. Wzniesiono wówczas pięćdziesiąt nowych bloków m. in. przy ul. Hetmańskiej i na Osiedlu WSK przy ul. Dąbrowskiego ${ }^{31}$ (rys. 5.).

Powiększanie obszaru poza linie torów kolejowych i koryto Wisłoka nastąpiło po 1960 roku. Powstawały kolejne osiedla, szkoły wyższe oraz szpitale. Dostosowanie miasta do pełnienia funkcji ośrodka wojewódzkiego poprzez budowę niezbędnych urzędów, zaplecza kulturalno-oświatowego i socjalnego, a także postępujący rozwój szkolnictwa wyższego przyczyniło się do szybkiego rozwoju demograficznego Rzeszowa. ${ }^{32}$ Tereny wzdłuż Wisłoka stały się terenami rekreacji i wypoczynku ${ }^{33}$. W wyniku postępującego rozwoju konieczne było

\footnotetext{
${ }^{29}$ M. Furtak, Centralny Okręg Przemystowy (COP) 1936-1939. Architektura i Urbanistyka, Kraków-Łódź 2014, s.86-87.

${ }^{30} \mathrm{~W}$. Hennig, Plany i koncepcje zagospodarowania przestrzennego miasta, [w:] Encyklopedia Rzeszowa, Rzeszów 2004, s.538.

31 P. Grata, Rozwój gospodarczy miasta, [w:] Dzieje Rzeszowa Tom IV, Rzeszów 2012, s.988987.

32 W. Bonusiak, Rozwój demograficzny Rzeszowa w latach 1945-1989, [w:] Dzieje Rzeszowa Tom IV, Rzeszów 2012, s. 988-987.

${ }^{33}$ W. Hennig, Rozwój przestrzenny miasta [w:] Encyklopedia Rzeszowa, Rzeszów 2004, s. 538.
} 


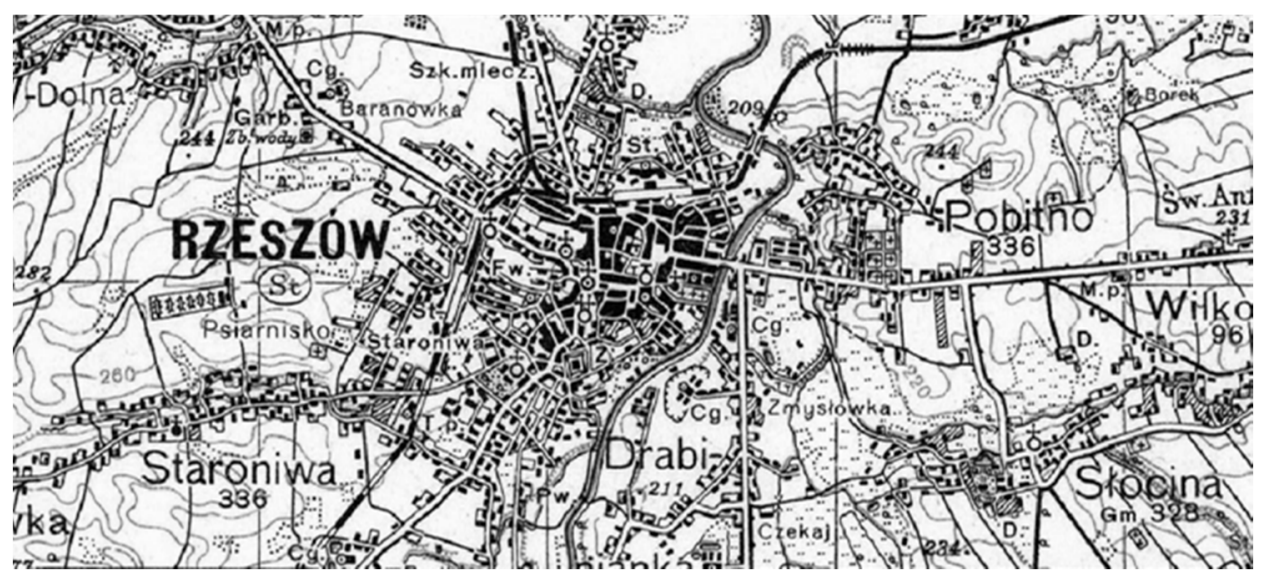

Rys. 4. Rzeszów mapa z 1938 r. Archiwum Map Wojskowego Instytutu Geograficznego, na podstawie: www.mapywig.org

Fig. 4. Map of Rzeszow in 1938. Archive of Maps of the Military Geographical Institute

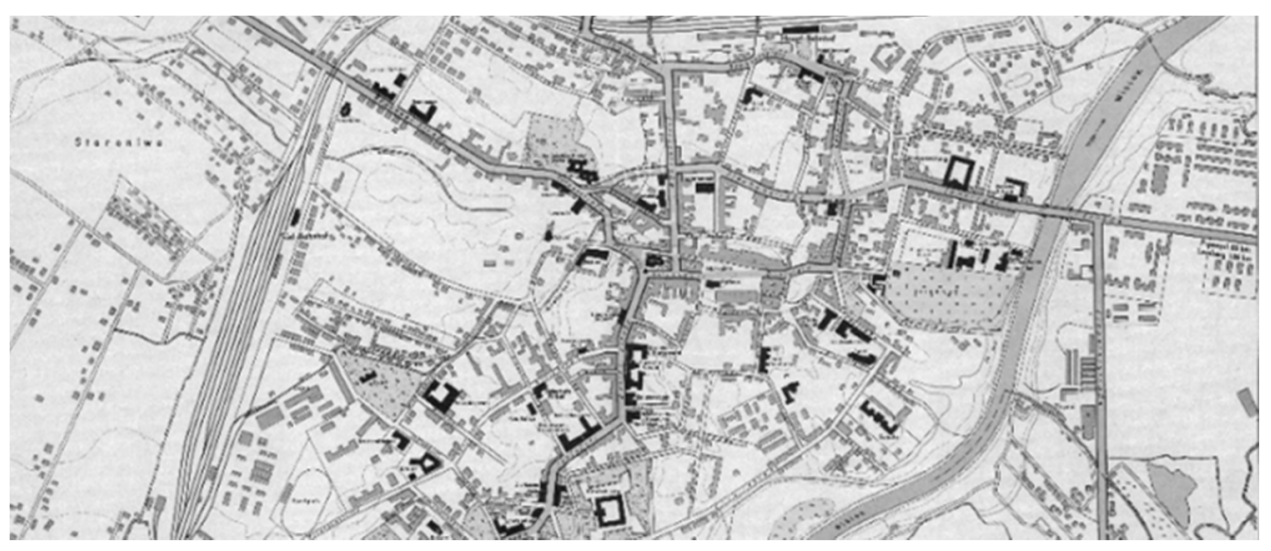

Rys. 5. Fragment planu Rzeszowa - 1944 r. Archiwum Map Wojskowego Instytutu Geograficznego, na podstawie: www.mapywig.org

Fig. 5. Part of Rzeszow plan - 1944. Archive of Maps of the Military Geographical Institute

rozbudowanie i dostosowanie urządzeń infrastruktury do obsługi miasta. Ze względu na brak wystarczających środków planowane inwestycje zostały rozciągnięte w czasie. Na początku lat 70 . zostały wybudowane dwa wiadukty, które usprawniły komunikację w kierunkach Wschód - Zachód oraz Północ Południe. ${ }^{34}$ Znaczną zmianę $\mathrm{w}$ układzie komunikacyjnym przyniosła budowa tzw. obwodnicy południowej. Realizacje te opierały się na planach zagospodarowania przestrzennego. Jednak rozwój nie był kompleksowy, co skutkowało zahamowaniem przekształceń $\mathrm{w}$ centrum miasta. ${ }^{35}$

${ }^{34}$ P. Grata, Rozwój gospodarczy miasta, [w:] Dzieje Rzeszowa Tom IV, Rzeszów 2012, s. 157.

${ }^{35}$ W. Hennig, Rozwój przestrzenny miasta [w:] Encyklopedia Rzeszowa, Rzeszów 2004, s. 538. 


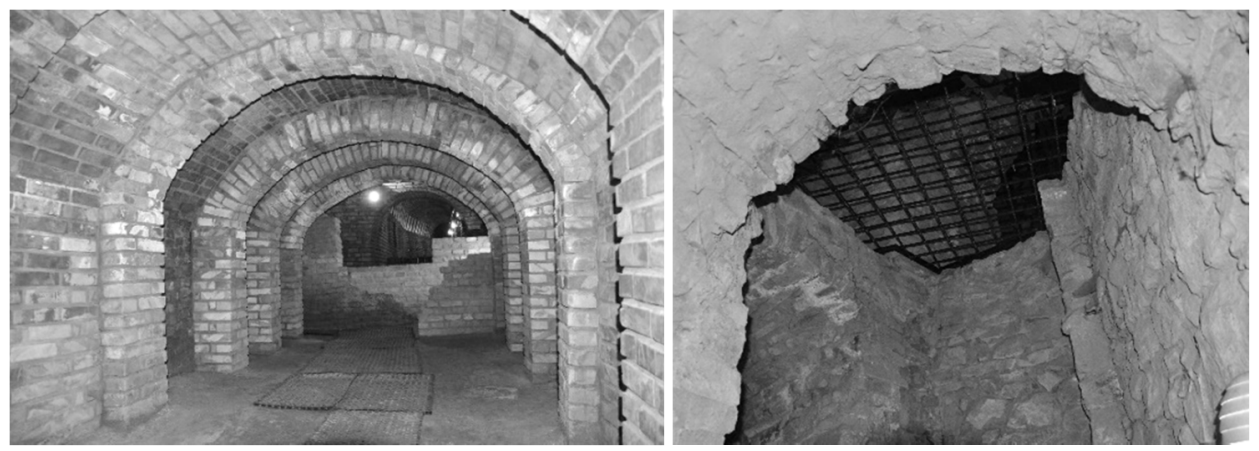

Rys. 6. Podziemna Trasa Turystyczna w Rzeszowie. Fot. Rafał Lichołai, 03. 2017

Fig. 6. Underground tourist route in Rzeszów. Fot. Rafał Lichołai, 03. 2017

Decyzję o zachowaniu i rewaloryzacji zabytkowej części Starego Miasta, władze Rzeszowa podjęły w roku 1973. Wówczas rozpoczęły się prace zmierzające do uzupełnienia zabudowy przyrynkowej oraz remonty kamienic wraz ze wzmocnieniem ich fundamentów. W 1994 roku została podjęta decyzja o utworzeniu Podziemnej Trasy Turystycznej i tym samym udostępnieniu piwnic. Mimo podjętych trzydzieści lat wcześniej działań, dopiero w latach 2005-2007 została uzupełniona zabudowa pierzei północnej przy płycie Rynku (rys. 6). ${ }^{36}$

$\mathrm{W}$ połowie lat 70. XX wieku, na prawym brzegu Wisłoka rozpoczęto budowę Nowego Miasta. Na tym największym rzeszowskim osiedlu zaplanowano budowę 11-piętrowych bloków dla około 40 tysięcy mieszkańców. Równolegle na osiedlu Zimowit rozpoczęto budowę domków jednorodzinnych. ${ }^{37} \mathrm{~W}$ roku 1977, po kolejnych włączeniach terenów, powierzchnia miasta wynosiła 5370 ha. Na skutek reformy administracyjnego podziału kraju, w 1975 roku Rzeszów stracił część środków, które przeznaczono na rozwój stolic nowych województw. To spowolniło rozwój miasta aż do kolejnej zmiany administracyjnej i ustanowienia Rzeszowa stolicą województwa podkarpackiego w 1999 roku. ${ }^{38}$

W latach 2006-2010 dokonano powiększenia obszaru Rzeszowa przez przyłączenie: Słociny i Załęża, Przybyszówki, Zwięczycy, Białej, Budziwoju oraz południowo-zachodniej części Miłocina. Od początku 2017 roku włączono również sołectwo Bzianka. W skutek zmiany granic, terytorium Rzeszowa powiększyło się ponad dwukrotnie. ${ }^{39}$

Formowanie układu urbanistycznego Rzeszowa było długim, wieloetapowym procesem. Podział na poszczególne fazy dotyczy kolejno pierwszych osad,

\footnotetext{
${ }^{36}$ J. Malczewska, Rewaloryzacja Rynku Starego Miasta w Rzeszowie [w:] Wiadomości Konserwatorskie $\mathrm{nr} 43 / 2015$, s. 7-8.

${ }^{37}$ W. Bonusiak, Rozwój przestrzenny..., [w:] Dzieje Rzeszowa Tom IV, Rzeszów 2012, s. 45.

${ }^{38}$ W. Hennig, Rozwój przestrzenny miasta [w:] Encyklopedia Rzeszowa, Rzeszów 2004, s.538.

${ }^{39}$ Dane Biura Rozwoju Miasta Rzeszowa z 2017 roku.
} 
założenia miasta lokacyjnego, formowania przedmieść, budowy zamku i jego późniejszej przebudowy. Następna faza wiąże się ze zniekształceniem układu urbanistycznego w okresie rozbiorów, aż do ponownego ożywienia w okresie autonomii galicyjskiej. Kolejny etap rozwoju nastąpił w okresie międzywojennym, a później podczas odbudowywania miasta po II wojnie światowej. Lata 60te stanowią następny etap przekształceń, mający wpływ na strukturę zabudowy i infrastruktury miasta. Początek XXI wieku to czas dynamicznego rozwoju Rzeszowa, który wiążę się z powiększaniem granic, rozbudową układu komunikacyjnego, budową osiedli, rozwojem strefy gospodarczej. Aktualnie przygotowywane są kolejne koncepcje związane z rozwojem struktury przestrzennej Rzeszowa.

\section{Literatura}

[1] Dzieje Rzeszowa. T. I, Rzeszów od najdawniejszych czasów do I rozbioru, Kiryk F. (red.), Krajowa Agencja Wydawnicza, Rzeszów 1994.

[2] Dzieje Rzeszowa. T. II, Rzeszów w czasach zaborów i niewoli (1772-1918), Kiryk F. (red.), Wydawnictwo Mitel, Rzeszów 1998.

[3] Dzieje Rzeszowa. T. III, Rzeszów w okresie międzywojennym i okupacji (19181944), Kiryk F. (red.), Wydawnictwo Libri Ressovienses, Rzeszów 2001.

[4] Dzieje Rzeszowa. T. IV, Rzeszów w latach 1945-1989, Bonusiak W. (red.), Wydawnictwo Mitel, Rzeszów 2012.

[5] Encyklopedia Rzeszowa, Draus J. (red.), RS DRUK, Rzeszów 2004.

[6] Furtak M., Centralny Okreg Przemystowy (COP) 1936-1939. Architektura i Urbanistyka, Księży Młyn, Kraków-Łódź 2014.

[7] Gosztyła M., Jagieła B., Konserwacja zabytków architektury- teoria i praktyka dziatań konserwatorskich na przykładzie reprezentatywnych kościołów Rzeszowa, Oficyna wydawnicza Politechniki Rzeszowskiej, Rzeszów 2015.

[8] Gutkowska J. B., Rzeszów. Rozpoznanie historyczne zabudowy przyrynkowej, Pracownia dokumentacji naukowo-historycznej oddział w Rzeszowie, Rzeszów 1974$-1976$.

[9] Hennig W. Rzeszowski alfabet miejsc często już zapomnianych i osób z nimi zwiazanych., Podkarpacki Instytut Książki i Marketingu, Rzeszów 2012.

[10] Kotarski H., Malicki K., Stolica podkarpacia wczoraj i dziś studium socjologiczne spotecznych aspektów przemian w Rzeszowie w latach 1989-2009, Wydawnictwo Uniwersytetu Rzeszowskiego, Rzeszów 2013.

[11] Kotula F., Tamten Rzeszów, czyli wędrówka po zakątkach i historii miasta, Wydawnictwo Zimowit, Rzeszów 1997.

[12] Malczewska J., Rewaloryzacja Rynku Starego Miasta w Rzeszowie [w:] Wiadomości Konserwatorskie nr 43/2015.

[13] Malczewski J., Kwolek R. Historia i Rozwój przestrzenny Rzeszowa od powstania do wspótczesności [w:] Renowacje i Zabytki 3/2015

[14] Malczewski J., Zamek w Rzeszowie, jego otoczenie i właściciele, Wydawnictwo Libri Ressovienses, Rzeszów 1995. 
[15] Nieć J., Rzeszowskie za Sasów: szkic historyczny, Rzeszów 1938.

[16]Pęckowski J., Dzieje miasta Rzeszowa do końca XVIII wieku : z 21. rycinami w tekście, Drukarnia Ed. Arvay, Rzeszów 1913.

[17] Rucka-Marmaj D., Letni pałac Lubomirskich w Rzeszowie, [w:] Renowacje i Zabytki 3/2015.

[18]Zawitkowska W., Zamoyski G., Przywileje miasta Rzeszowa XIV-XIX wieku, Wydawnctwo Mitel, Rzeszów 2014.

\section{URBAN PLANNING OF THE CITY OF RZESZOW IN HISTORICAL ASPECTS}

\section{S u m m a r y}

The article describes the development of the spatial structure of the city of Rzeszow. Formation of this complex was a process lasting several centuries. The process of forming the fabric of the city has been divided into stages, for which groundbreaking historical events were a determinant. The article characterizes urban planning Rzeszow, starting from the description of the archaeological research on the first settlements in the area, and ending with the modern times. The accompanying maps and charts illustrate the changes in the spatial structure of the city. The primary aim of this article was to present the structured process of urban capital of Subcarpathian. The text cites the relevant aspects of the rich and varied history of the city, showing their importance in the process of forming the structure of today's Rzeszow. The article can help to determine the directions of further development of the city.

Keywords: urban, city, spatial development, architecture Rzeszow

Przestano do redakcji: 09.06.2017 $r$.

Przyjęto do druku: 01.09.2017 r. 